\title{
CORRESTONDENCE.
}

\section{FISH REMAINS.}

Sir,--In the last number of the "G "GotoaIST," some observations were added to your interesting pages by Mr.E. R. Lankester, on the Pteraspis remains at Cradley; he would lead geologists to believe that perfect plates of this fish are found there as plentifully as blackberries in the hedgerows. To nse the words of your correspondent, "three or four fine specimens in every block that one turns." This is a little too strong; and differs totally from our experience of the spot. The proper clue to the discrepancy would consist perhaps in an appeal to the "respectable Scotchman" who presides over this pisciforous domain, who would probably enlighten us in this instance; and certainly provide us with as rich a haul as Mr. Lankester had, and at the same rate, viz., in exchange for that current coin of the realm that Scotchmen are not a whit behind the rest of Her Majesty's lieges in loving. Wo should be much indebted to Mr. Lankester if he would inform us on what authority he calls these Cradley fish, $P$, rostratus, as we poor ignorami always thought them to be $P$. Lewisii and $P$. Lloydii. It is well that this note should appear, if it only save anv young enthusiast from instantly betaking himself to Cradley, fresh from your last number, and provided with too large a bag for the occasion. I believe, and the Quarry to us is familiar ground; that he would have his expectations clipped, and his temper tried. Still, do not, young geologist, turn aside from Cradley, but repair thither, with thy dinner in thy satchel, and thy hammer in thy pouch, prepared for a long day; and though thou verifiest not Mr. Lankester's account, forsooth, thou wilt not be disappointed.

MAITEUTS,

\section{ANNUAL MEETING OF GEOLOGISTS.}

Drar Sir,-I am delighted to see the suggestions you have thrown out in last month's GEoLoarst, and in order that something tangible may come of it, I wonld propose that a British Geological Association Meeting be held next year at the ancient city of Hereford; on the same plan as the British Archrological Association Meetings. From the number of railways, and readiness of access, Hereford is advisable for the London geologists, as also for the members of the Liverpool, Manchester and Oswestry Clubs who could reach it in four hours time, while the Cotswold; Malvern, and Warwickshire Clubs are close by. If the members of these associations alone would join, a very respectable meeting would be the consequence: and I need not say that the Woolhope members, who have their headquarters at Hereford, would leave no stone unturned to welcome their brethren of the hammer. Excursion-trains might be run each day to places of well-known geological interest : to Church Stretton and the Longmynd Hills; to Pontypool and the South Wales Basin; to Newnham and the Triassic cliffs of the Severn; to the Malverns; to the Woolhope Valley of elevation; to the Usk Silurians; to the Ludlow district and the Clee Hills. I will venture to say that no place in the kingdom could offer a more varied or interesting neighbourhood in which such an association might inagurate its annual gatherings. Last, but not least, Hereford offers plenty of accommodation for any number of geologists that might attend.

Beaufort, August 19. I am, dear Sir, yours faithfally, G. P. BeVAN. 